\title{
The fate of introduced streptomycetes, plasmid and phage populations in a dynamic soil system
}

\author{
Neil Cresswell, ${ }^{1}$ Paul R. Herron, ${ }^{1}$ Venetia A. Saunders ${ }^{2}$ and \\ Elizabeth M. H. Wellington ${ }^{1 *}$ \\ 'Department of Biological Sciences, University of Warwick, Coventry CV4 7AL, UK \\ 'School of Science and Technology, Liverpool Polytechnic, Liverpool L3 $3 A F, U K$
}

(Received 9 October 1991; revised 9 December 1991; accepted 11 December 1991)

\begin{abstract}
Populations of Streptomyces lividans and S. violaceolatus were monitored in natural soil amended with nutrients. The fates of a multicopy plasmid pIJ673, and an actinophage, KC301, were determined and the extent of gene transfer was estimated. The soil was incubated for $60 \mathrm{~d}$ during which time 'spent' soil was periodically removed followed by addition of fresh, uninoculated soil. Maximum numbers of bacteria and phage inoculants occurred at $15 \mathrm{~d}$; this correlated with a peak in the amount of plasmid DNA detected and total numbers of transconjugants recovered. A KC301 lysogen of S. lividans was also recovered at this time. Plasmid DNA was monitored by two methods, bead-beating and SDS/heat lysis; the latter was specific for mycelium while the former released DNA from spores and mycelium. Southern blots of soil DNA only showed the presence of plasmid DNA in SDS/heat lysis extracts from $15 \mathrm{~d}$ and $17 \mathrm{~d}$ samples, whereas positive signals were obtained throughout the experiment from bead-beaten extracts. The results confirmed that a well-developed mycelium was necessary for conjugation, phage infection, multiplication and lysogeny in soil.
\end{abstract}

\section{Introduction}

Bacterial gene transfer in soil has been investigated for a range of genera (reviewed by Stotzky \& Babich, 1986; Stotzky et al., 1990) and Streptomyces species have been studied with respect to conjugation in soil (Rafii \& Crawford, 1988, 1989; Bleakley \& Crawford, 1989; Wellington et al., 1988, 1990a, b; Clewlow et al., 1990). Genetic exchange by transformation or transduction has not yet been reported, although lysogeny has been demonstrated in nutrient-amended soil only (Herron \& Wellington, 1990). Most studies have used simple batch microcosms to investigate the fate of marked plasmids and phages in soil. However, in soil the supply of nutrients is discontinuous in space and time (Nedwell \& Gray, 1987), whereas the study of micro-organisms in enclosed microcosms does not allow for input of nutrients and 'turnover' of fresh soil. Since gene transfer requires an active growth phase, fluctuations in growth in response to nutrient availability may result in changes in the extent of transfer of introduced plasmids and phages within streptomycete populations.

The aim of this study was to investigate the correlation between microbial activity and genetic exchange within

- Author for correspondence. Tel. (0203) 523184; fax (0203) 523568. a dynamic model soil system. A fed-batch microcosm was designed to allow successive addition and withdrawal of soil. Previous work with closed microcosms has shown that streptomycete growth in soil follows a cyclical pattern of germination and sporulation after inoculation into sterile nutrient-amended soil and, to a lesser extent, in nonsterile soil (Wellington et al., $1990 a$; Herron \& Wellington, 1990). If nutrient and microsite availability in the batch microcosms were limiting growth then the addition of fresh amended soil should allow further cycles of germination accompanied by a period of phage activity or plasmid transfer. In sterile nutrient-amended soil, germination reached a peak $2 \mathrm{~d}$ after inoculation; phage numbers also peaked at this time and transconjugants could easily be detected (Wellington et al., 1990b; Herron \& Wellington, 1990). Monitoring and detection of micro-organisms in environmental samples poses a number of problems (reviewed by Pickup, 1991), particularly if the organism is filamentous. A viable plate count can only be used as an indication of changes in activity. The use of sporespecific extraction techniques coupled with molecular methods for direct detection of plasmid DNA were employed in this study to establish population trends and investigate the relationship between activity and gene 
Table 1. Inoculum used for soil pots

\begin{tabular}{ccccc}
\hline \hline $\begin{array}{c}\text { Treatment } \\
\left(\begin{array}{c}\text { replicates } \\
\text { of each): }\end{array}\right.\end{array}$ & $\begin{array}{c}\text { S. lividans } \\
\text { TK24 } \\
\left(\text { c.f.u. } \mathbf{g}^{-1}\right)\end{array}$ & $\begin{array}{c}\text { S. violaceolatus } \\
\text { ISP 5438 }+ \text { pIJ673 } \\
\left(\text { c.f.u. } \mathbf{g}^{-1}\right)\end{array}$ & $\begin{array}{c}\text { KC301 } \\
\left(\text { p.f.u. } \mathbf{g}^{-1}\right)\end{array}$ & $\begin{array}{c}\text { Data } \\
\text { presented }\end{array}$ \\
\hline A & $1.05 \times 10^{5}$ & - & - & Figs 2, 4 \\
B & - & $1.04 \times 10^{5}$ & - & Fig. 4 \\
C & $1.05 \times 10^{5}$ & $1.04 \times 10^{5}$ & - & Figs 1, 2, 6, 7 \\
D & - & - & $1.04 \times 10^{5}$ & Fig. 5 \\
E & $1.05 \times 10^{5}$ & - & $1.04 \times 10^{5}$ & Figs 3, 5 \\
F & - & - & - & Figs 3, 5 \\
\hline \hline
\end{tabular}

transfer in the filamentous, spore-forming bacteria Streptomyces lividans and Streptomyces violaceolatus.

\section{Methods}

Bacterial strains, phage and plasmids. The strains used were as previously described for plasmid transfer studies and phage-host interactions (Wellington et al., 1990a; Herron \& Wellington, 1990). Steptomyces violaceolatus ISP 5438, transformed with pIJ673, was used as donor. pIJ673 (kindly supplied by T. Kieser, John Innes Institute, Norwich, UK) is a derivative of pIJ101, a conjugative, multicopy plasmid (Kieser et al., 1982) with cloned resistance determinants against viomycin $(v p h)$, thiostrepton $(t s r)$ and neomycin $(\mathrm{Tn} 5)$ inserted into nonessential regions ( $T$. Kieser, unpublished data). In soil experiments Streptomyces lividans TK24 (no known plasmids, streptomycin-resistant mutant) was used as a recipient. The phage $\mathrm{KC} 301$ (kindly supplied by K. Chater, John Innes Institute, Norwich, UK), a derivative of $\phi C 31$ (Lomovskaya et al., 1980; Chater, 1986) contained tsr. TK24 was used as host both for phage propagation in vitro and in soil crosses. Strains were grown at $30^{\circ} \mathrm{C}$ on R5 agar (Hopwood et al., 1985), supplemented with appropriate antibiotics (Streptomycin, $50 \mu \mathrm{g}$ $\mathrm{ml}^{-1}$; thiostrepton, $50 \mu \mathrm{g} \mathrm{ml}^{-1}$; and neomycin $10 \mu \mathrm{g} \mathrm{ml}^{-1}$; all from Sigma). Filtered spore suspensions were prepared by the method of Hopwood et al. (1985) and stored in $20 \%(\mathrm{w} / \mathrm{v})$ glycerol at $-20{ }^{\circ} \mathrm{C}$. Phage were grown overnight at $30^{\circ} \mathrm{C}$ in soft nutrient agar overlays (supplemented with $8 \mathrm{~mm}-\mathrm{Ca}\left(\mathrm{NO}_{3}\right)_{2}$ and $10 \mathrm{~mm}-\mathrm{MgSO}_{4}$ ) seeded with S. lividans TK24 (Hopwood et al., 1985). High-titre lysates of KC301 were prepared by the method of Stuttard (1979) and stored at $4{ }^{\circ} \mathrm{C}$.

Soil treatments. The soil used in this study was taken from a local wheatfield site at Cryfield, University of Warwick (Wellington et al., $1990 a$ ). Soil was nutrient-amended with $1 \%(w / w)$ starch (soluble, BDH) and $1 \%(w / w)$ chitin (crabshell, Sigma). Six treatments were devised, each consisting of nine $200 \mathrm{~g}$ replicate soil pots (Table 1 ). Inoculants were added in distilled $\mathrm{H}_{2} \mathrm{O}$ to give a final moisture content of $15 \%(\mathrm{w} / \mathrm{w})(-0.67 \mathrm{bar})$. Microcosms were incubated at $22^{\circ} \mathrm{C}$, and at days $0,2,15,17,30,32,45,47$ and 60 one microcosm from each of the six treatments was destructively sampled. After $15 \mathrm{~d}$ (and every subsequent fifteenth day) the remaining microcosms were mixed and $50 \%$ of their weight replaced with fresh, uninoculated, nonsterile nutrient-amended soil. This newly constituted soil was then rewetted to $15 \%(w / w)$ moisture, thoroughly mixed and incubated further at $22{ }^{\circ} \mathrm{C}$. Samples taken at 15,30 and $45 \mathrm{~d}$ were removed before dilution of the inoculant populations with fresh soil. Soil sampled was treated as follows: three $1 \mathrm{~g}$ aliquots were removed and extracted with $\frac{1}{4}$-strength Ringer's solution (Wellington et al., 1990a); $100 \mathrm{~g}$ of soil was extracted for spore counts (Herron \& Wellington, 1990); and $20 \mathrm{~g}$ was extracted for phage enumeration using method C of Lanning \& Williams (1982). Three aliquots of the centrifugation supernatant for phage extraction were filtered, serially diluted and assayed for KC301 in triplicate as described by Hopwood et al. (1985). The remaining soil. was then used to calculate the soil moisture $(\%, w / w)$ at each sample day. Inoculants were enumerated on RASS (Herron \& Wellington, 1990), containing rifampicin $\left(10 \mu \mathrm{g} \mathrm{ml}^{-1}\right.$, Sigma $)$, cycloheximide $\left(50 \mu \mathrm{g} \mathrm{ml}^{-1}\right.$, Sigma $)$ and nystatin $\left(50 \mu \mathrm{g} \mathrm{ml}^{-1}\right.$, Sigma). Further antibiotics were included for the enumeration of specific strains: streptomycin $\left(10 \mu \mathrm{g} \mathrm{ml} l^{-1}\right)$ for $S$. lividans TK 24; neomycin $\left(10 \mu \mathrm{g} \mathrm{ml}^{-1}\right)$ and thiostrepton $\left(50 \mu \mathrm{g} \mathrm{ml}^{-1}\right)$ for S. violaceolatus ISP 5438 harbouring pIJ673; streptomycin $(10 \mu \mathrm{g}$ $\left.\mathrm{ml}^{-1}\right)$, neomycin $\left(10 \mu \mathrm{g} \mathrm{ml}^{-1}\right)$ and thiostrepton $\left(50 \mu \mathrm{g} \mathrm{ml}^{-1}\right)$ for $S$. lividans TK 24 transconjugants. S. lividans TK 24 lysogens were detected using streptomycin $\left(10 \mu \mathrm{g} \mathrm{ml}^{-1}\right)$ and thiostrepton $\left(50 \mu \mathrm{g} \mathrm{ml} \mathrm{ml}^{-1}\right)$. Indigenous streptomycetes were isolated and enumerated on RASS containing only antifungal agents.

Confirmation of phenotypes. Putative transconjugants were confirmed by extraction of plasmid DNA using the alkaline lysis procedure of Hopwood et al. (1985). Digestion with PstI yielded a characteristic fiveband restriction pattern following electrophoresis in a $1 \%(\mathrm{w} / \mathrm{v})$ agarose gel (Wellington et al., 1990a). Putative lysogens were probed with ${ }^{32} \mathrm{P}$ labelled KC301 DNA by the colony hybridization method of Hopwood et al. (1985). These isolates were also checked for spontaneous phage release (Herron \& Wellington, 1990).

Detection of pIJ673 using soil DNA extraction. Two methods for the recovery of plasmid DNA from soil were used; both involved modifications of the direct lysis procedures of Ogram et al. (1987), and the development of these methods is described in Cresswell et al. (1991). The first method lysed micro-organisms in the soil by SDS/heat treatment, and allowed efficient lysis of streptomycete mycelia. The second method involved bead-beating, which lysed both spores and mycelia.

$S D S /$ heat lysis. Ten grams of soil, resuspended in $20 \mathrm{ml}$ sodium phosphate buffer $(0 \cdot 12 \mathrm{M}, \mathrm{pH} 8$; SPB $)$ with $1.5 \%(\mathrm{w} / \mathrm{v})$ SDS, was heated at $70^{\circ} \mathrm{C}$ for $1 \mathrm{~h}$ then shaken on a flask shaker (maximum setting, $10 \mathrm{~min})$. Samples were then centrifuged $(1660 \mathrm{~g}, 10 \mathrm{~min})$, the supernatant removed and the pellet re-extracted with SPB. Supernatants were pooled and centrifuged $(13800 \mathrm{~g}, 20 \mathrm{~min})$ and DNA in the supernatant was precipitated by the addition of $0.5 \mathrm{vol}$. polyethylene glycol $6000(50 \%, w / v)$ and incubation at $4{ }^{\circ} \mathrm{C}$ overnight. The sample was then centrifuged $(2260 \mathrm{~g}, 10 \mathrm{~min})$. The resultant pellet was resuspended in $5 \mathrm{ml}$ TE buffer $(10 \mathrm{~mm}$-Tris, $1 \mathrm{~mm}$-EDTA) and extracted twice with equal volumes of TE-saturated phenol. Phases were separated by centrifugation and the phenol phase was reextracted with TE buffer. The aqueous phases were pooled and extracted with chloroform/isoamyl alcohol $(24: 1, v / v)$. DNA was finally precipitated with ethanol at $-20^{\circ} \mathrm{C}$, using standard procedures. The final DNA pellet was resuspended in $100 \mu \mathrm{I}$ TE buffer.

Bead-beating lysis. Ten grams of soil was suspended in $25 \mathrm{ml} \mathrm{SPB}$. The suspension was decanted into a $40 \mathrm{ml}$ bead-beating bottle and glass beads $(0 \cdot 10-0.11 \mathrm{~mm}$ diameter) added to fill the bottle. Samples were subjected to five 1 min bursts of bead-beating using a Braun bead- 
beater. The suspension of beads and soil was recovered and the bottle washed with $5 \mathrm{ml} \mathrm{SPB}$, which was added to the extracted soil. Samples were then centrifuged at $1660 \mathrm{~g}$ for $10 \mathrm{~min}$. The supernatant was retained and the pellet re-extracted twice with SPB by vortexing and centrifugation. Supernatants were pooled and subsequent processing was the same as for the SDS/heat lysis protocol except that phenol/chloroform/isoamyl alcohol $(25: 24: 1$, by vol.) was used for extraction.

DNA was extracted by both methods from treatments $C$ and $F$ from day 2 onwards at each sample time. Following extraction from soil, DNA samples $(40 \mu \mathrm{l})$ were subjected to electrophoresis in $1 \%(w / v)$ agarose gels, following standard procedures, before being Southern blotted and probed with ${ }^{32}$ P-labelled pIJ673 DNA. Labelling reactions were carried out using a random-primed DNA-labelling kit (Boehringer-Mannheim). Quantification of plasmid DNA was achieved by densitometric analysis of autoradiographs. A Molecular Dynamics 300A Computing Scanning Densitometer was used to obtain standard curves for known amounts of pure plasmid present on each blot, and from these the amount of plasmid DNA present in the DNA extracts could be calculated. Autoradiographs were developed after various lengths of exposure; this was necessary to optimize quantification.

Statistical analysis. Where possible, all points on graphs are means of three replicate samples counted in triplicate. Statistical analysis was done with the MINITAB statistical software package (Minitab Statistical Software, State College, PA, USA). Minimum significant differences (MSD) were calculated from analysis of variance using the TukeyKramer method (Petersen, 1985; Fry, 1989). Regression analysis of the survival data for $S$. litidans TK24 (treatment A); $S$. violaceolatus (treatment B) and $\mathrm{KC} 301$ (treatment D) was done to determine differences in the rates of decline in population numbers. In addition a theoretical rate of decline was determined by halving the population number at each dilution time starting from the recoverable counts at $0 \mathrm{~d}$ and assuming no growth or death occurred. Significant differences were calculated by Student's $t$-test, comparing the slopes of the lines of best fit using the equation:

$$
t=\frac{b-(\text { hypothesized value) }}{\text { estimated SD of } b} \quad(\text { Ryan } \text { et al., 1985) }
$$

\section{Results}

Inoculant population levels in treatment $\mathrm{C}$ (Table 1), inoculated with both $S$. lividans TK24 and $S$. violaceolatus ISP 5438, were maintained during the first $15 \mathrm{~d}$ (Fig. 1 $a, b$ ). Subsequently the titre of both organisms decreased as the inoculum was diluted by the addition of fresh soil. Counts obtained from the Ringer's dilution plate method were uniformly higher than those obtained by the spore extraction method. At $60 \mathrm{~d}$ inoculants were undetectable by dilution plating but both strains were readily enumerated by spore extraction (Fig. $1 a, b$ ). $S$. lividans TK24 reached a peak at $15 \mathrm{~d}$, before declining in a step-wise manner for the remainder of the experiment (Fig. $2 a, b$ ) and this trend was reproduced in other treatments (data not shown). Indigenous streptomycetes showed fluctuations in counts between $10^{7}$ and $10^{8}$ c.f.u. (g soil) $^{-1}$, reaching a peak at $17 \mathrm{~d}$ (Fig. $3 a, b$ ), whereas inoculant populations peaked at $15 \mathrm{~d}$, as did transconjugant numbers and plasmid DNA (see Fig. $6 a, b$ ).
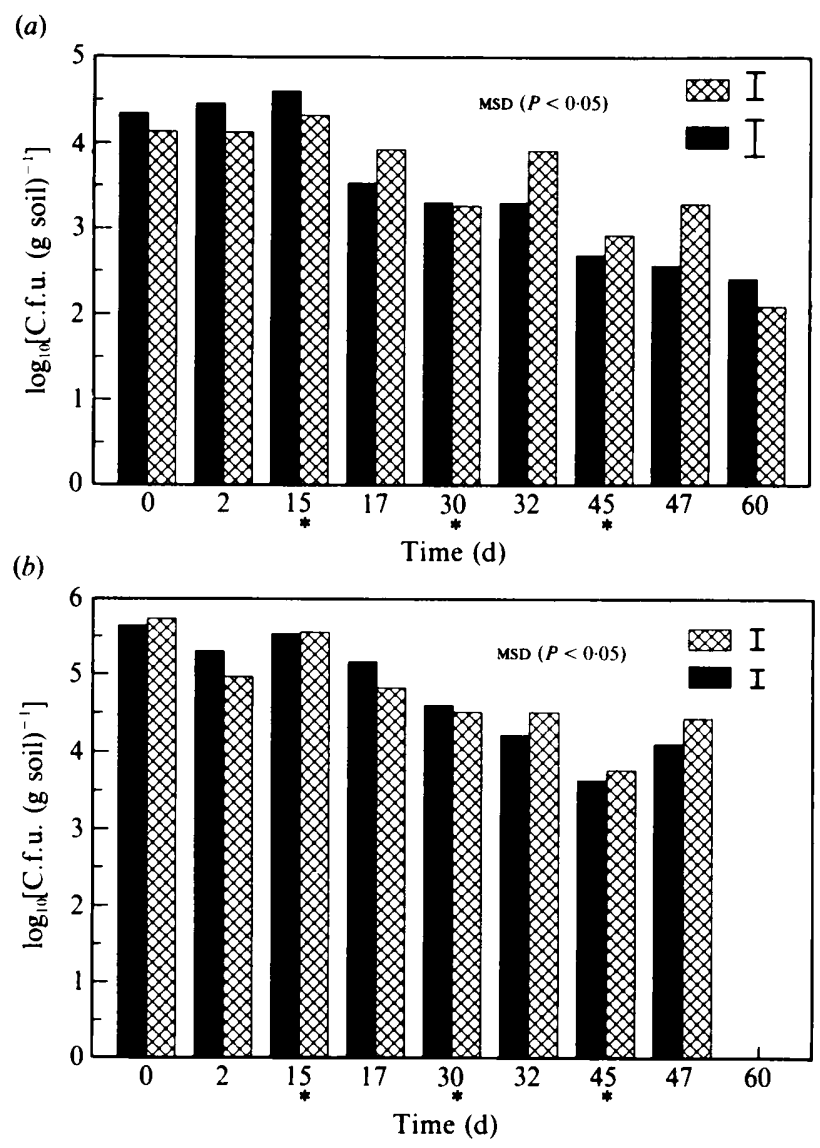

Fig. 1. Growth and survival of $S$. lividans TK $24(\mathbb{\square})$ and $S$. violaceolatus ISP5438 harbouring plasmid pIJ673 (ख) in treatment C: $(a)$ sporespecific extraction method; (b) dilution plate method. The asterisks indicate dilution time.

Significant growth of either $S$. lividans or $S$. violaceolatus was not detected after $15 \mathrm{~d}$. The rate of decline in $S$. lividans TK24, S. violaceolatus ISP 5438 and the phage KC301 was significantly greater $(P<0.01)$ than the predicted decline, as shown by regression analysis (Fig. $4 a, b, c)$. This indicates that the dilution effect was not the sole factor contributing to the decline in inoculant population numbers. The survival of KC 301 was similar to that of its host; phage numbers declined throughout the $60 \mathrm{~d}$ experiment and after $15 \mathrm{~d}$ counts from soils containing KC301 (treatments D and E) were indistinguishable from those of indigenous phage in treatment $F$ (Fig. 5a). Indigenous actinophage were undetectable at $0 \mathrm{~d}$ but were detected at $2 \mathrm{~d}$; this population declined significantly between $2 \mathrm{~d}$ and $15 \mathrm{~d}(P<0.05)$, probably due to a reduction in soil moisture content over the initial $15 \mathrm{~d}$ incubation. Indigenous phage numbers were maximal at $17 \mathrm{~d}$ after the system was 'fed' and rewetted at $15 \mathrm{~d}$; this corresponded with the maximum numbers of recoverable indigenous streptomycetes (Fig. $5 b$ ). After $17 \mathrm{~d}$, indigenous phage numbers declined during the 

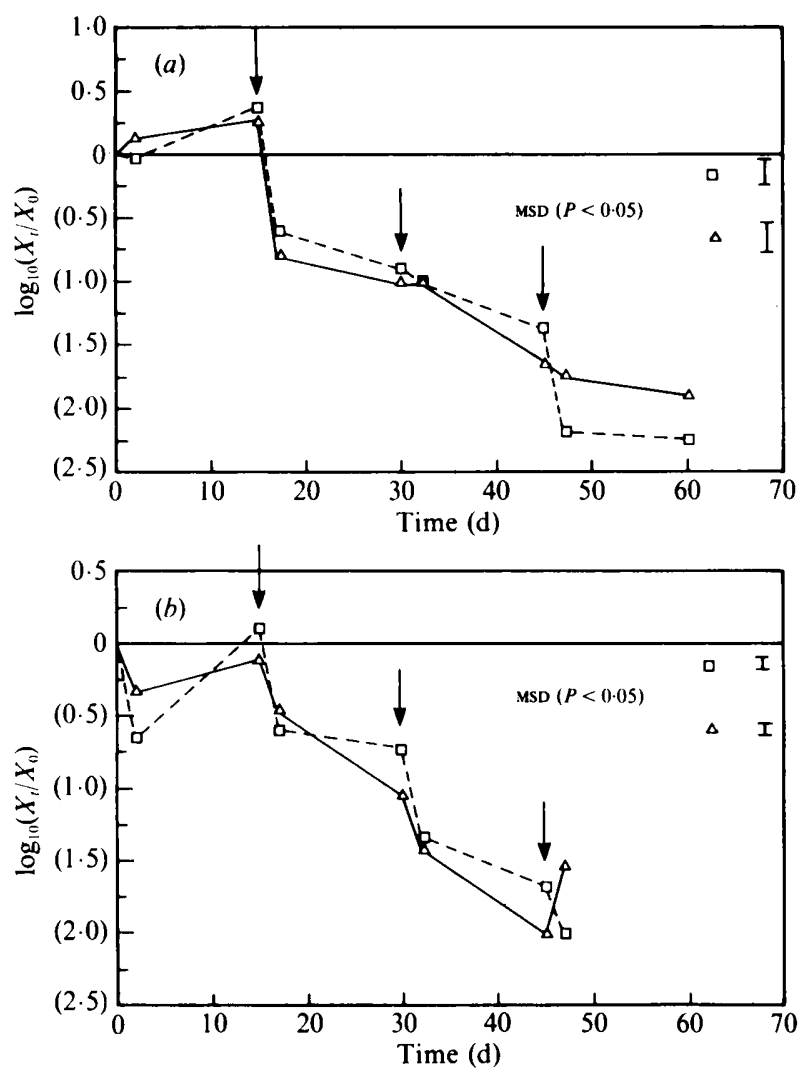

Fig. 2. Proportional change in the populations of $S$. lividans TK24 in treatments $A\left(\square^{---} \square\right)$ and $C(\triangle-\triangle):(a)$ spore-specific extraction method; $(b)$ dilution plate method. The arrows indicate dilution time. $X_{0}$ is the count at time $0, X_{\mathrm{t}}$ that at time $t . X$ is c.f.u. (g dry wt soil) ${ }^{-1}$.

remainder of the experiment, corresponding with a significant decline in indigenous streptomycete population (Fig. $3 a$ ). Each time the soil was 'fed' phage counts increased; the increases at these points were not significant $(P<0.05)$ for $\mathrm{KC} 301$ but were markedly so for indigenous actinophage between $15 \mathrm{~d}, 17 \mathrm{~d}$ and $30 \mathrm{~d}$, $32 \mathrm{~d}$ (Fig. 5a). One thiostrepton-resistant $S$. lividans TK 24 colony was detected at $15 \mathrm{~d}$ from treatment $\mathrm{E}$, using the spore extraction method; it was confirmed as a lysogen by screening for spontaneous phage release and by probing with ${ }^{32} \mathrm{P}$-labelled KC301 DNA. Problems occurred with fungal contamination at low dilutions of the final suspension of the spore extraction method, thus hindering the screening of these plates for lysogens. No streptomycetes were isolated from control soils that were resistant to the antibiotics used to select for inoculant genotypes, with the exception of streptomycin and rifampicin used to select for $S$. lividans TK24; such indigenous colonies were differentiated from $S$. lividans TK 24 by colony pigmentation.

Transconjugants were readily detected using both extraction methods from treatment $\mathrm{C}$ (Fig. $6 a$ ). Counts peaked at around $15 \mathrm{~d}$, before declining to undetectable
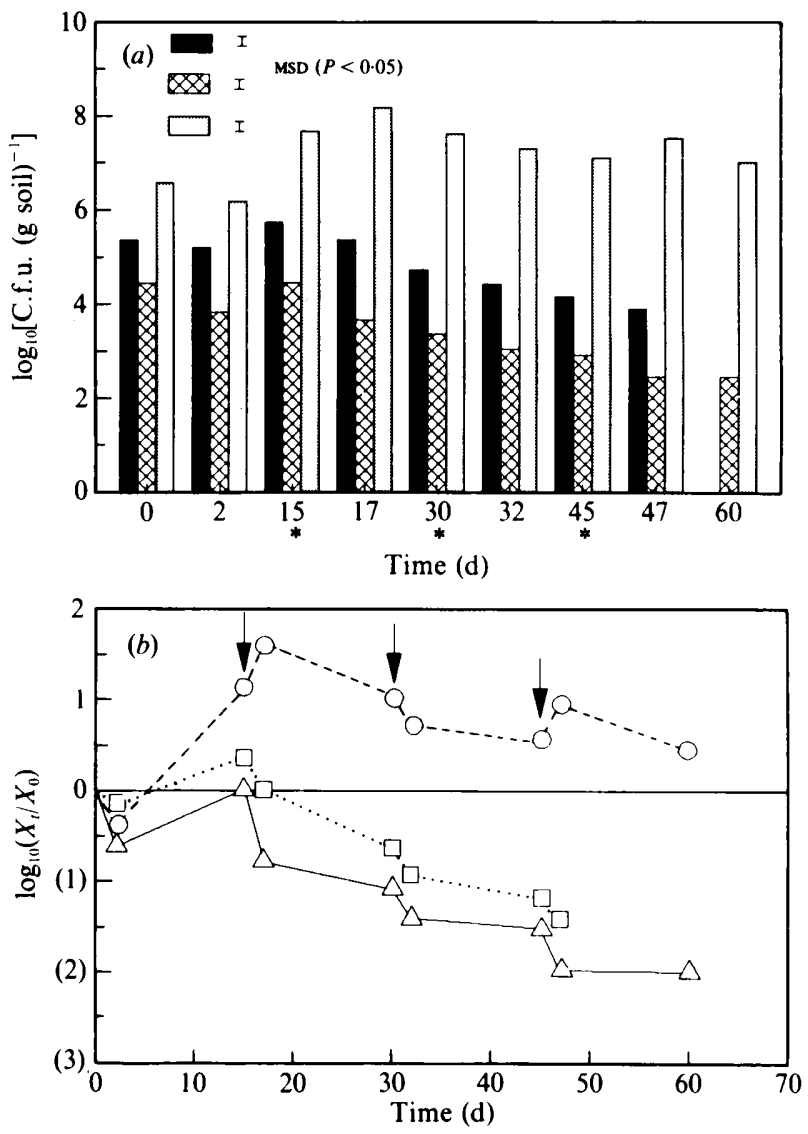

Fig. 3. (a) Comparison of population levels of $S$. lividans TK24 and indigenous streptomycetes: $S$. lividans enumerated by the sporespecific extraction method (B) and the dilution plate method $(\boldsymbol{D})$ in treatment $\mathrm{E}$; indigenous streptomycetes enumerated by the dilution plate method in treatment $\mathrm{F}$ (图). Asterisks indicate dilution time. (b) Proportional change in populations of $S$. lividans TK24 and indigenous streptomycetes: $S$. lividans TK24 enumerated by the spore-specific $(\triangle-\triangle)$ and dilution plate $(\square \ldots \square)$ methods; indigenous streptomycetes enumerated by the dilution plate method $\left(\mathrm{O}_{---} \mathrm{O}\right)$. Arrows indicate dilution time. $X_{0}$ is the count at time $0, X_{t}$ that at time $t . X$ is c.f.u. (g dry wt soil) $)^{-1}$.

levels, although one colony was detected at $60 \mathrm{~d}$ using the spore extraction method.

Plasmid-bearing strains were also monitored using soil DNA extractions. Total soil DNA was isolated from treatments $\mathrm{C}$ and $\mathrm{F}$ using the bead-beating and SDS/heat lysis extraction methods (Fig. 7a-d). Plasmid DNA in beat-beaten extracts from treatment $C$ was quantified by densitometric analysis (Fig. 6b). In SDS/heat lysis extracts plasmid DNA was only detected at $15 \mathrm{~d}$ and $17 \mathrm{~d}$ in soil from treatments B (data not shown) and C (Fig. $7 b$ ). The signals at $17 \mathrm{~d}$ obtained from the SDS/heat lysis extracts were much weaker than those from $15 \mathrm{~d}$ extracts (Fig. $7 b$ ). Soil at $15 \mathrm{~d}$ was extracted prior to the removal of 'spent' soil and addition of fresh nutrient-amended soil. In extracts obtained by bead-beating (treatment $\mathrm{C}$ ), 

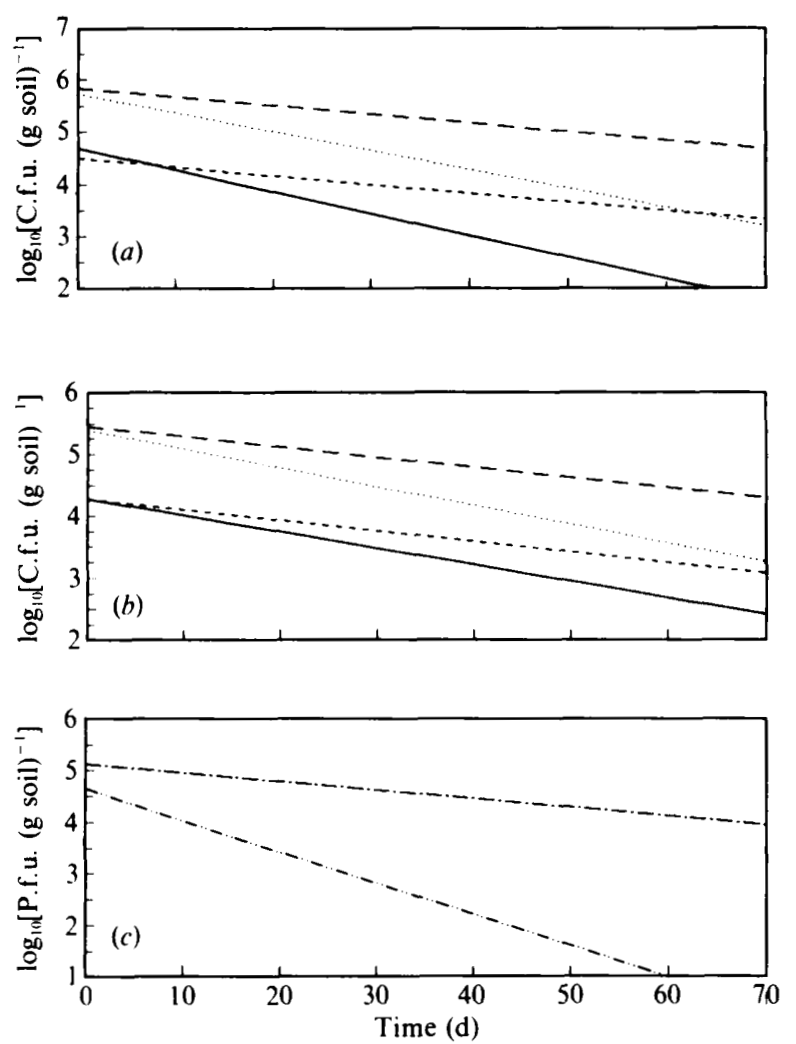

Fig. 4. Theoretical and actual rates of decline in inoculant spore and total propagule counts for $(a) S$. lividans TK24 in treatment A, (b) $S$. riolaceolatus harbouring $\mathrm{pI} J 673$ in treatment $\mathrm{B}$, and $(c)$ phage $\mathrm{KC} 301$ in treatment D. Spore counts, observed (-); theoretical (--); total counts, observed $(. .$.$) ; theoretical (--)$; phage counts, observed $(-\cdot-)$ : theoretical $(-\cdot-)$.

plasmid signal was detected throughout the experiment, with a peak yield of plasmid at $15 \mathrm{~d}$ (Fig. $6 b, 7 b, 7 d$ ). During the experiment, maximum signal for plasmid DNA was consistently obtained at $15 \mathrm{~d}$. No signals were obtained from treatment $F$ soil extracted by either method.

\section{Discussion}

During the first $15 \mathrm{~d}$ of the experiment, populations of all streptomycete inoculants were maintained. The rapid subsequent decline in inoculant populations indicated that they were unable to colonize nonsterile fresh soil and substrates. Perhaps this was due to available sites in the fresh soil being occupied by the resident microbial population. Comparison with a theoretical decline, based on halving populations at each dilution point, showed that death and predation of streptomycetes may also have been affecting survival, causing a significant increase in the rate of decline. The data suggest that the
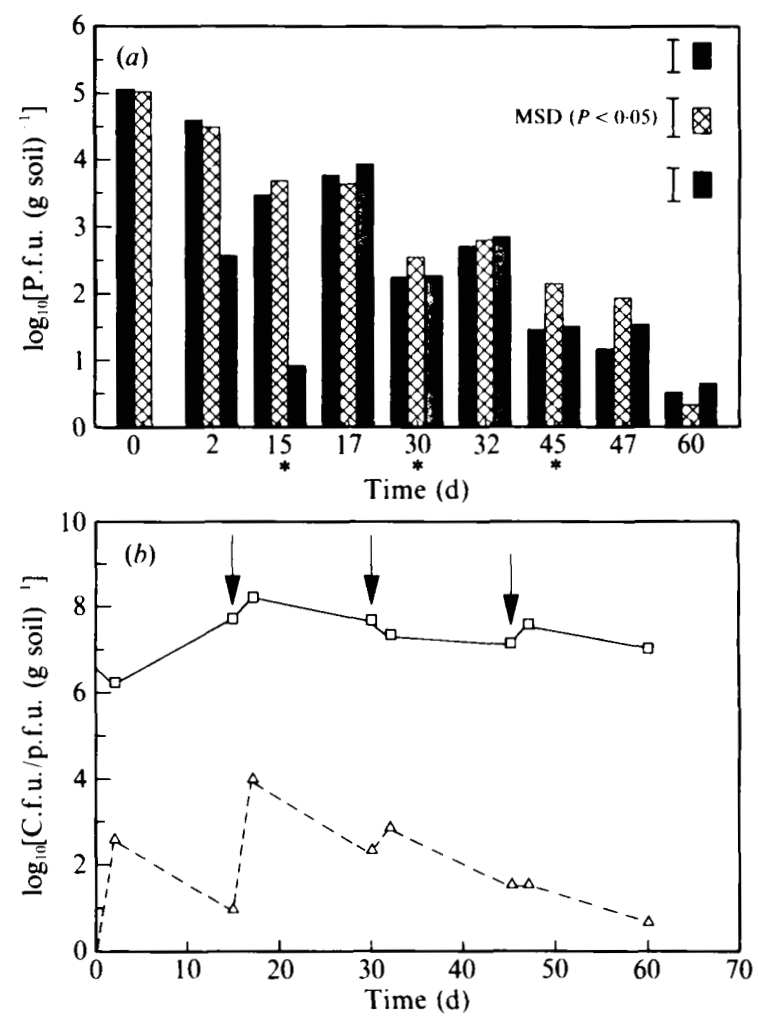

Fig. 5. Correlations between phage and host populations in soil. (a) Fate of KC30l and indigenous phage in treatments D, E and F:KC301 in treatment $\mathrm{D}(\boldsymbol{\square}) ; \mathrm{KC} 301+\mathrm{TK} 24$ in treatment $\mathrm{E}(\mathrm{B})$; indigenous phage in treatment $\mathrm{F}(\mathrm{E})$. Asterisks indicate dilution time. (b) Comparison of changes in indigenous streptomycete and phage populations in treatment F. $\square-\square$, Streptomycetes enumerated by the dilution plate count method: $\triangle--\triangle$. phage. Arrows indicate dilution time.

inoculants were present in the mycelial state after the initial $15 \mathrm{~d}$ incubation period, but it is difficult to predict if plasmid transfer occurred to any significant extent after this phase. Continued recovery of transconjugants may be due to their growth and sporulation. Secondary plasmid transfer events via the indigenous streptomycete population may also have taken place. Studies using SDS/heat and bead-beating lysis methods have shown that the cellular origin of streptomycete plasmid DNA can be determined in soil (Cresswell et al., 1991). Detection of plasmid DNA from soil-borne spores using SDS/heat lysis required a minimum of approximately $10^{6}$ spores (g soil) ${ }^{-1}$. Detection using bead-beating gave two orders of magnitude greater sensitivity for detection of plasmid DNA from spores. As the total numbers of plasmid-containing spores in the treatments did not exceed $10^{6}$ c.f.u. $\mathrm{g}^{-1}$ (Fig. $1 a, b$ ) the inoculant level was below that of the minimum detection by SDS/lysis. Plasmid was only detected in extracts obtained from SDS/heat lysis at $15 \mathrm{~d}$ and $17 \mathrm{~d}$ in soil from treatments B and $\mathrm{C}$; the data indicate that the inoculum had 

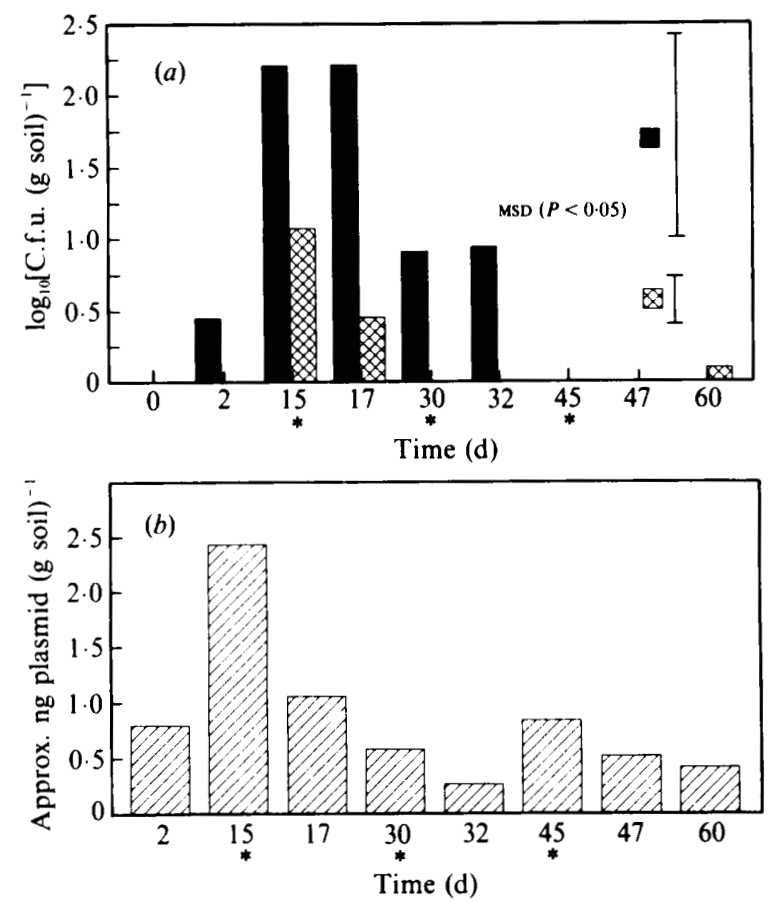

Fig. 6. (a) Detection of $S$. lividans TK24 transconjugants in treatment $C$ by the dilution plate $(\square)$ and spore-specific extraction ( $)$ methods; $(b)$ detection of plasmid DNA in bead-beaten extracts from treatment $C$ $(囚)$. Asterisks indicate dilution time.

germinated and after $2 \mathrm{~d}$ produced sufficient mycelial growth to be detected by SDS/heat lysis. No plasmid DNA was detected at $2 \mathrm{~d}$ in soil extracted by SDS/heat lysis from treatment $C$, although the initial inoculum size of plasmid-containing host was $1.04 \times 10^{5}$ c.f.u. ( $\mathrm{g}$ soil) $)^{-1}$ (Table 1). Cresswell et al. (1991) detected plasmid in SDS/heat lysis extracts from sterile soil inoculated with $1 \times 10^{4}$ spores $\mathrm{g}^{-1}$ and incubated for $2 \mathrm{~d}$ at $21^{\circ} \mathrm{C}$. It is therefore possible that much of the $S$. violaceolatus ISP 5438 inoculum was still present as spores at $2 \mathrm{~d}$ in the nonsterile soil used in this study. No further fluctuations in plasmid DNA were observed in the SDS/heat lysis extracts, suggesting that no significant regrowth of plasmid-containing mycelia occurred. The bead-beaten extracts also contained most plasmid DNA at $15 \mathrm{~d}$ (Fig. $7 d$ ) but there was evidence for further growth and sporulation before $45 \mathrm{~d}$ (Figs $1 a$ and $6 b$ ).

Phage titres increased when the soil was 'fed' at $15 \mathrm{~d}$ and $30 \mathrm{~d}$, in a manner similar to that reported by Germida (1986), indicating that the virus was propagating in a host which must have been in the mycelial state (Lomovskaya et al., 1972) (Fig. 5a). Previous studies (Herron \& Wellington, 1990; Wellington et al., 1990a) indicated that in nonsterile unamended soil systems, germination of $S$. lividans TK24 was very limited. However, a significant increase in c.f.u. was observed in nonsterile nutrient-amended soil (Wellington et al.,
$1990 a$ ). In the present study growth occurred within the first $15 \mathrm{~d}$ but no significant increase in inocula population levels was observed. The soil used in this study was collected at a time when the indigenous bacterial populations were high and the soil was not dried below $7 \%(w / w)$ moisture content. This may have resulted in a lack of growth and establishment of the inoculum due to the increased competition from indigenous microflora.

It was also clearly demonstrated that $S$. lividans TK 24 and $S$. violaceolatus ISP $5438 \mathrm{did}$ not spread and colonize nonsterile nutrient-amended soil but appeared to compete poorly with indigenous bacteria. This may reflect the long-term maintenance of these strains under laboratory conditions. S. lividans is also a streptomycinresistant mutant, which can result in reduced fitness (Garrette \& Wittman, 1974). The congruence between different methods for monitoring plasmid stability and survival in soil was also clearly demonstrated. The extraction and probing of soil DNA provided a sensitive method for monitoring plasmid in soil. The use of differential extraction techniques indicated that plasmid-containing strains were present mainly as spores after $30 \mathrm{~d}$, which was supported by spore counts for treatment $\mathrm{C}$ (Fig. 1a). All the monitoring techniques showed that inoculant populations peaked at $15 \mathrm{~d}$, and this coincided with the highest number of transconjugants recovered together with the appearance of one lysogen. Also at this time the highest level of plasmid DNA in the mycelial phase was detected by the SDS/heat lysis extraction procedure.

The fed-batch system was not designed as a true model of soil field conditions but it did, by dilution and withdrawal, provide a dynamic system resulting in population fluctuations. It has been demonstrated that direct monitoring of a plasmid can be achieved and provides data on population changes where plate counts failed; this was also demonstrated by Selenska \& Klingmüller $(1991 a, b)$ for plasmid-encoded nif and chromosomally inserted $\mathrm{Tn} 5$ genes in an Enterobacter agglomerans host. KC301 numbers did show periodic increases in titre which correlated with addition of fresh soil and nutrients. These fluctuations were analogous to the rise and fall of phage titres predicted by a mathematical model of actinophage-host interactions in soil (Williams et al., 1986; Manchester, 1986). The paucity of lysogens isolated related to the decline in phage and host numbers below the threshold level predicted by previous batch systems (Herron, 1991). This suggested that most phage infections were virulent, which may be indicative of old or senescing mycelium becoming infected. Phage infection, under laboratory conditions, is highest when using exponentially growing hyphal tips (Lomovskaya et al., 1972). This point highlights how little is known about the response of a 

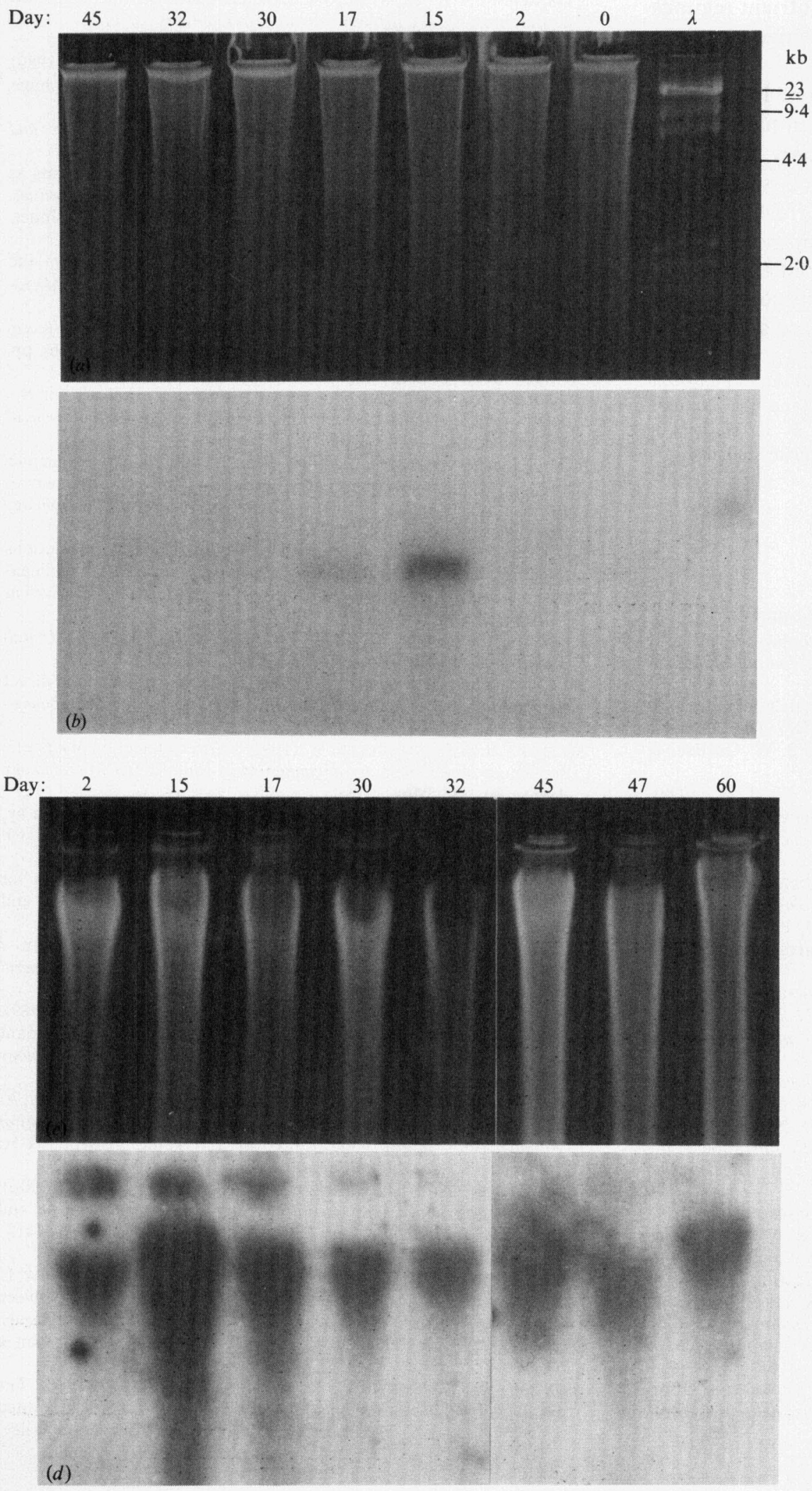

Fig. 7. Agarose gels of DNA extracted from soii and corresponding Southern blots probed witt radiolabelled pIJ673 DNA. $(a, b)$ SDS/heat lysis extracts of DNA from treatment $C ;(c, d)$ bead. beaten extracts of DNA from treatment $C$. $\lambda$. HindIII-restricted $\lambda$ DNA size markers. Distinct DNA bands are not clearly visible in the agarose gels, especialy for SDS/heat lysis extracts, because of the humic acid and phenolic contamination: this ran ahead of the DNA and removed much of the ethidium bromide with a tendency to smear the samples. 
phage to the metabolic activity of its host. Future work will go on to study the effect of different nutrient regimes on the ability of phage $\mathrm{KC} 301$ to lysogenize or lyse a streptomycete host in vitro.

Previous studies of streptomycete survival in soil have indicated that spores survive well in nonsterile soil (Wang et al., 1989). In the present study there was evidence of death and/or predation of spores and mycelium. It is possible that addition of fresh nutrients caused spores to germinate, making them more vulnerable to phage infection and predation. This may be a more realistic model of soil field conditions compared to batch systems where no fresh nutrients are added.

We gratefully acknowledge financial support from the Commission of the European Communities [CII 0545-UK] and the Natural Environment Research Council [GST/02/191B)]. P. R. H. held a Science \& Engineering Research Council postgraduate studentship.

\section{References}

Bleakley, B. H. \& Crawford, D. L. (1989). The effects of varying moisture and nutrient levels on the transfer of a conjugative plasmid between Streptomyces species in soil. Canadian Journal of Microbiology' 35, 544-549.

Chater, K. F. (1986). Streptomyces phage and their applications to Streptomyces genetics. In The Bacteria, vol. IX: The Antibiotic Producing Streptomyces, pp. 119-158. Edited by S. W. Queener \& L. E. Day. Orlando: Academic Press.

Clewlow, L. J., Cresswell, N. \& Wellington, E. M. H. (1990). Mathematical model of plasmid transfer between strains of streptomycetes in soil microcosms. Applied and Environmental Microbiology 56, 3139-3145.

Cresswell, N., Wellington, E. M. H. \& Saunders, V. A. (1991). Detection and quantification of Streptomyces violaceolatus plasmid DNA in soil. Letters in Applied Microbiology 13, 193-197.

FRY, J. C. (1989). Analysis of variance and regression in aquatic bacteriology. Binary 1, 83-88.

Garrette, A. \& Wittman, H. G. (1974). Structure of bacterial ribosomes. Advances in Protein Chemistry 27, 277-347.

GERMIDA, J. J. (1986). Population dynamics of Azospirillum brasilense and its bacteriophage in soil. Plant and Soil 90, 117-128.

HERRON, P. R. (1991). Interactions hetween actinophage and streptomycetes in soil. PhD. thesis, University of Warwick.

Herron, P. R. \& Wellington, E. M. H. (1990). New method for extraction of streptomycete spores from soil and application to the study of lysogeny in sterile and nonsterile soil. Applied and Entironmental Microbiology 56, 1406-1412.

Hopwood, D. A., BibB, M. J., Chater, K. F., Kieser, T., Bruton, C. J., Kieser, H. M., Lydiate, D. J., SMith, C. P., WARD, J. M. \& SCHREMPF, H. (1985). Genetic Manipulation of Streptomyces - a Laboratory Manual. Norwich: The John Innes Institute.

Kieser, T., HopWOOD, D. A., Wright, H. M. \& THOMPSON, C. J. (1982). pIJ101, a multi-copy broad host-range Streptomyces plasmid: functional analysis and development of DNA cloning vectors. Molecular and General Genetics 185, 223-238.

LANNING, S. \& Williams, S. T. (1982). Methods for the direct isolation and enumeration of actinophage in soil. Journal of General Microbiology 128, 2063-2071.
Lomovskaya, N. D., Mkrtumian, N. M., Gostimaya, N. L. \& DANILENKo, V. N. (1972). Characterisation of the temperate actinophage $\phi \mathrm{C} 31$ isolated from Streptomyces coelicolor A3(2). Journal of Virology 9, 258-262.

Lomovskaya, N. D., Chater, K. F. \& Mkrtumian, N. M. (1980). Genetics and molecular biology of Streptomyces bacteriophage. Microbiological Reviews 44, 206-229.

MANCHESTER, L. (1986). Modelling the interactions of streptomycetes and their phage. PhD thesis, University of Manchester.

Nedwell, D. B. \& Gray, T. R. G. (1987). Soils and sediments as matrices for microbial growth. In Ecology of Microbial Communities, pp. 21-54. Edited by M. Fletcher, T. R. G. Gray \& J. G. Jones. Cambridge: Cambridge University Press.

Ogram, A., SaYler, G. S. \& Barkay, T. (1987). The extraction and purification of microbial DNA from sediments. Journal of Microbiological Methods 7, 57-66.

Petersen, R. G. (1985). Separation of means. In Design and Analysis of Experiments (Statistics: Textbooks and Monographs, Volume 66), pp. 72-111. New York: Marcel Dekker.

PICKUP, R. W. (1991). Development of molecular methods for the detection of specific bacteria in the environment. Journal of General Microbiology 137, 1009-1019.

RAFI, F. \& CRAWFORD, D. L. (1988). Transfer of conjugative plasmids and mobilisation of a non-conjugative plasmid between Streptomyces strains on agar and in soil. Applied and Environmental Microbiology 54, 1334-1340.

Rafil, F. \& Crawford, D. L. (1989). Donor/recipient interactions affecting plasmid transfer among Streptomyces species: a conjugative plasmid will mobilise non-transferable plasmids in soil. Current Microbiology 19, 115-121.

RYAN, B. F., JoIner, B. L. \& RYAN, T. A., JR (1985). Minitab Handbook, 2nd edn. Boston: PWS-Kent.

SElENSKA, S. \& KLINGMÜlLER, W. (1991 $a$ ). DNA recovery and direct detection of $\operatorname{Tn} 5$ sequences from soil. Letters in Applied Microbiology $13,21-24$

SELENSKA, S. \& KLINGMÜLLER, W. (1991 $b$ ). Direct detection of nif-gene sequences of Enterobacter agglomerans in soil. FEMS Microbiology Letters 80, 243-246.

Stotzky, G. \& BAвiCH, H. (1986). Survival of, and genetic transfer by, genetically engineered bacteria in natural environments. Advances in Applied Microbiology 31, 93-138.

Stotzky, G., Devanas, M. A. \& Zeph, L. R. (1990). Methods for studying bacterial gene transfer in soil by conjugation and transduction. Advances in Applied Microbiology 35, 57-169.

StUTTARD, C. (1979). Transduction of auxotrophic markers in a chloramphenicol producing strain of Streptomyces. Journal of General Microbiology 110, 479-482.

Wang, Z., Crawford, D. L., Pometto, A. L. \& Rafil, F. (1989). Survival and effects of wild type, mutant and recombinant Streptomyces in a soil ecosystem. Canadian Journal of Microbiology 35, 535-543.

Wellington, E. M. H., Saunders, V. A., Cresswell, N. \& Wipat, A. (1988). Plasmid transfer between streptomycetes in soil. In Biology of Actinomycetes, pp. 301-305. Edited by Y. Okami, T. Beppu \& H. Ogawara. Tokyo: Japan Scientific Societies Press.

Wellington, E. M. H., Cresswell, N. \& SAunders, V. A. (1990a). Growth and survival of streptomycete inoculants in sterile and nonsterile soil. Applied and Environmental Microbiology 56, 14131419.

Wellington, E. M. H., Cresswell, N., Herron, P. R., Clewlow, L. J., SaUnders, V. A. \& Wipat, A. $(1990 b)$. Gene transfer between streptomycetes in soil. In Bacterial Genetics in Natural Environments, pp. 216-230. Edited by J. C. Fry \& M. J. Day. London: Chapman \& Hall

Williams, S. T., Mortimer, A. M. \& Manchester, L. (1986). The ecology of soil bacteriophage. In Phage Ecology, pp. 157-180. Edited by S. M. Goyal, C. P. Gerba \& G. Bitton. New York: John Wiley. 